\title{
Persepsi Mahasiswa Fakultas Ekonomi Terhadap Program Kewirausahaan Pada Perguruan Tinggi
}

\author{
Soenartomo Soepomo \\ Fakultas Ekonomi dan Bisnis, Universitas Ma Chung \\ E-mail: soenartomo.soepomo@machung.ac.id
}

\begin{abstract}
Government promoted-entrepreneurship program for students has been launched in 2009. Various perception among students toward the program are explained using stereotype interpretion, impression management, and emotion as perception elements in this research. The objectives of this research are: 1) Analyzing simultanously influences of stereotype interpretion, impression, and emotion on the program in a University; 2) studying the partial inffluence of stereotype interpretion, impression management, and emotion on the program; 3) Finding the variable that has the most dominant influence on the program. Results; Perceptions partially and simultanously influence the entrepreneurship program. Students show good responsiveness towards the program. Their perceptions partially contribute the program (66\%). Perception on stereotype interpretetion share a contribution of $20.50 \%$. Perception on impression management contributes an amount of 27, $7 \%$. Finally perception on emotional intensity give a contribution of $28.30 \%$.
\end{abstract}

Keywords: perception, emotion, entrepreneurship program

\section{PENDAHULUAN}

Salah satu karakteristik perguruan tinggi sebagai masyarakat ilmiah adalah suasana dinamis dalam berbagai kegiatan mahasiswa, mulai dari kegiatan yang bersifat ilmiah melalui proses perkuliahan di kelas, forum diskusi, seminar, hingga aktivitas yang sifatnya pengembangan bakat minat seperti olahraga dan kesenian. Berbagai kegiatan tersebut bertujuan menumbuhkembangkan kebiasaan berpikir ilmiah di kalangan mahasiswa, tidak mudah putus asa, dan mengembangkan sportivitas yang pada gilirannya kelak diharapkan mahasiswa memiliki kepribadian unggul di masyarakat.

Pelaksanaannya akan berhasil dengan baik, apabila didukung oleh iklim kampus yang kondusif yakni kampus yang bisa memberikan kepastian kualitas hasil belajar dalam suasana yang aman, damai, dan harmonis. Di satu sisi upaya yang dilakukan oleh manajemen kampus untuk menciptakan lingkungan belajar yang harmonis akan tercapai, jika mahasiswa memiliki pengalaman yang menyenangkan atau telah merasakan kondusifitas kebahagiaan bergaul dalam lingkungan kampus.

Pengalaman beradaptasi dengan lingkungan kampus merupakan dimensi persepsi yang penting, sebab menurut Ivancevic et al. (2006) persepsi adalah proses di mana seorang individu memberikan arti pada lingkungan. Hal tersebut melibatkan pengorganisasian dan penerjemahan berbagai stimulus menjadi pengalaman psikologis. Dengan demikian pengalaman yang positif akan memberikan arti plus pada lingkungan, sebaliknya pengalaman tidak kondusif berpengaruh pada ketidaksetiaan mahasiswa pada lingkungan akademik.

Sehubungan dengan semakin pentingnya lingkungan kampus, maka dibutuhkan suatu dukungan kemandirian mahasiswa dalam mensikapi atau bereaksi terhadap berbagai program kampus, termasuk program kewirausahaan untuk mahasiswa yang telah digulirkan sejak tahun 2009 oleh pemerintah. Program ini bertujuan mengembangkan potensi wirausaha muda khususnya mahasiswa, agar kelak setelah menyelesaikan studi mampu menciptakan peluang kerja. Pada konteks ini, respon mahasiswa terhadap program kewirausahaan yang diinterpretasikan melalui penerjemahan stereotip, manajemen kesan, dan emosi sebagai unsur persepsi menjadi penting diperhatikan sebagai suatu barometer kelancaran program kewirausahaan di kampus.

Searah dengan uraian pada latar belakang, maka dikemukakan rumusan masalah penelitian sebagai berikut:

1. Apakah ada pengaruh simultan pemberian stereotip, manajemen kesan, dan emosi terhadap program kewirausahaan ?

2. Apakah ada pengaruh parsial pemberian stereotip, manajemen kesan, dan emosi terhadap program kewirausahaan?

3. Dari ketiga variabel yang ada variabel mana pengaruhnya paling dominan terhadap program kewirausahaan?

Adapun yang menjadi tujuan penelitian adalah: 
1. Menganalisis pengaruh simultan pemberian stereotip, manajemen kesan, dan emosi terhadap program kewirausahaan.

2. Menganalisis pengaruh parsial pemberian stereotip, manajemen kesan, dan emosi terhadap program kewirausahaan.

3. Menganalisis variabel yang pengaruhnya paling dominan terhadap program kewirausahaan.

Adapun manfaat penelitian sebagai berikut:

1. Secara empiris. Penelitian ini diharapkan dapat menjadi salah satu kebijakan untuk memperkuat program kewirausahaan di lingkungan Perguruan Tinggi.

2. Secara Praktis. Hasil penelitian diharapkan menjadi wadah ekonomi mikro produktif dalam mengembangkan perilaku wirausaha di kalangan mahasiswa.

\section{KAJIAN TEORITIS}

Luthans (2006) menyatakan persepsi merupakan interpretasi unik dari suatu situasi, bukan rekaman situasi. Singkatnya persepsi merupakan proses kognitif kompleks yang menghasilkan gambaran dunia yang unik, yang mungkin agak berbeda dari realita, atau persepsi dianggap sebagai penyaring. Robbins dan Timothy (2008) menuturkan persepsi merupakan proses di mana individu mengatur dan menginterpretasikan manajemen kesan-manajemen kesan sensoris mereka guna memberikan arti bagi lingkungan mereka.

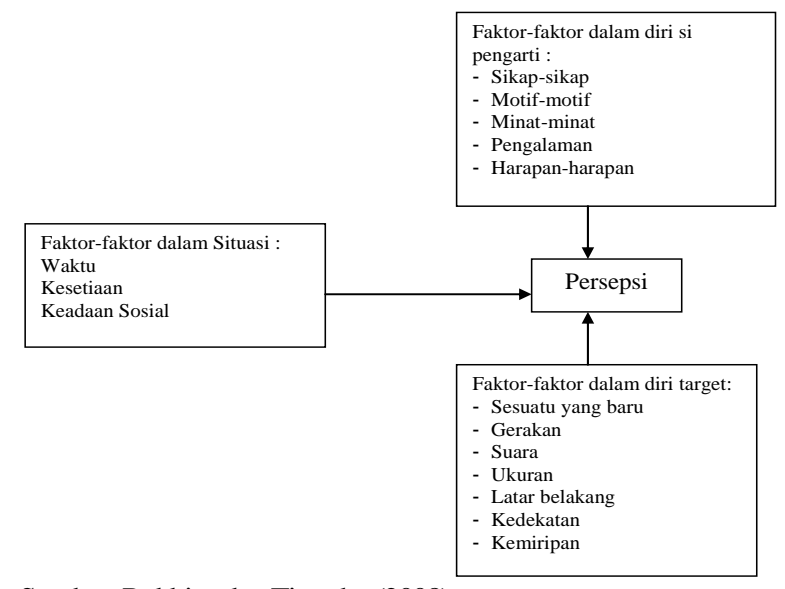

Sumber: Robbins dan Timothy (2008)

\section{Gambar 1. Faktor-Faktor yang Mempengaruhi Persepsi}

Kerangka pengembangan kewirausahaan di kalangan mahasiswa dirasakan sangat penting. Karena mahasiswa adalah 'agent of change' yang diharapkan mampu menanamkan ciri-ciri, sifat dan watak serta jiwa kewirausahaan atau jiwa 'entrepreneur' bagi masa depannya. Disamping itu jiwa 'entrepreneur' juga sangat diperlukan mahasiswa, karena melalui jiwa ini, mahasiswa akan memiliki orientasi mengisi waktu luang yang lebih efisien, kreatif, inovatif, produktif serta mandiri.

Instruksi Presiden No. 4 Th 1995 tanggal 30 Juni 1995 tentang Gerakan Nasional Memasyarakatkan dan Membudayakan Kewirausahaan, mengamanatkan kepada seluruh masyarakat dan bangsa Indonesia, untuk mengembangkan program-program kewirausahaan. Inpres tersebut dikeluarkan bukan tanpa alasan. Pemerintah menyadari betul bahwa dunia usaha merupakan tulang punggung perekonomian nasional, sehingga harus digenjot sedemikian rupa melalui berbagai Departemen Teknis maupun institusi institusi lain yang ada di masyarakat. Melalui gerakan ini pada saatnya budaya kewirausahaan diharapkan menjadi bagian dari etos kerja masyarakat dan bangsa Indonesia, sehingga dapat melahirkan wirausahawanwirausahawan baru yang handal, tangguh dan mandiri.

Dari segi karakteristik perilaku, Wirausaha (entepreneur) adalah mereka yang mendirikan, mengelola, mengembangkan, dan melembagakan perusahaan miliknya sendiri. Wirausaha adalah mereka yang bisa menciptakan kerja bagi orang lain dengan berswadaya. Definisi ini mengandung asumsi bahwa setiap orang yang mempunyai kemampuan normal, bisa menjadi wirausaha asal mau dan mempunyai kesempatan untuk belajar dan berusaha.

Berwirausaha melibatkan dua unsur pokok (1) peluang dan, (2) kemampuan menanggapi peluang, Berdasarkan hal tersebut maka definisi kewirausahaan adalah "tanggapan terhadap peluang usaha yang terungkap dalam seperangkat tindakan serta membuahkan hasil berupa organisasi usaha yang melembaga, produktif dan inovatif."

Dalam kehidupan keseharian, manusia akan selalu dihadapkan problema hidup yang harus dipecahkan dengan menggunakan berbagai sarana dan situasi yang dapat dimanfaatkan. Kemampuan seperti itulah yang merupakan salah satu inti kecakapan hidup (life skill). Artinya kecakapan yang selalu diperlukan oleh seseorang di manapun ia berada, baik yang berstatus peserta didik, pekerja, guru, pedagang, maupun orangtua. Pengertian life skill adalah kecakapan yang dimiliki seseorang untuk mau dan berani menghadapi problema hidup dan kehidupan secara wajar tanpa merasa tertekan, kemudian secara proaktif dan kreatif mencari serta menemukan solusi sehingga akhirnya mampu mengatasinya.

Kecakapan hidup (life skill) dapat dipilah menjadi lima bagian, ialah kecakapan mengenal diri (self awarness), kecakapan berpikir rasional (thinking skill), kecakapan sosial (social skill), kecakapan 
akademik (academic skill), dan kecakapan vokasional (vocational skill) (Depdiknas, 2002).

(1) Kecakapan mengenal diri (self awareness) atau kecakapan personal (personal skill), adalah kecakapan yang diperlukan bagi seseorang untuk mengenal dirinya secara utuh. Kecakapan ini mencakup:

a) Penghayatan diri sebagai makhluk Tuhan.

b) Penghayatan diri sebagai anggota keluarga dan masyarakat.

c) Penghayatan diri sebagai warga negara.

d) Menyadari dan mensyukuri kelebihan dan kekurangan diri.

e) Menjadikan kelebihan dan kekurangan sebagai modal dalam meningkatkan diri agar rmanfaat bagi diri dan lingkungannya.

(2) Kecakapan berpikir rasional (thinking skill) adalah kecakapan yang diperlukan dalam pengembangan potensi berpikir, mencakup:

a) Kecakapan menggali dan menemukan informasi (information searching).

b) Kecakapan mengolah informasi dan mengambil keputusan (information processing and decision making skills).

c) Kecakapan memecahkan masalah secara kreatif (creative problem solving skill).

(3) Kecakapan sosial ataukecakapan interpersonal (social skill) mencakup:

a) kecakapan komunikasi dengan empati (communication skill). Empati, sikap penuh pengertian dan seni komunikasi dua arah, perlu ditekankan, karena yang dimaksud berkomunikasi bukan sekedar menyampaikan pesan, tetapiisi dan sampainya pesan, disertai dengan 'manajemen kesan' baik, akan menumbuhkan hubungan yang harmonis.

b) kecakapan bekerjasama.

(4) Kecakapan akademik (academic skill) atau kemampuan berpikir ilmiah, mencakup komponenkomponen:

a) Kemampuan melakukan identifikasi variabel.

b) Kemampuan merumuskan hipotesis.

c) Kemampuan melakukan penelitian.

(5) Kecakapan vokasional (vocational skill), adalah keterampilan yang dikaitkan dengan berbagai bidang pekerjaan tertentu yang terdapat di masyarakat. Secara sederhana dapat dibuat skema pembagian kecakapan hidup yang perlu ditanamkan kepada peserta didik.

\section{METODE PENELITIAN}

Metode penelitian yang digunakan adalah metode survei, yaitu penelitian yang mengambil sampel dari suatu populasi dan menggunakan kuesioner sebagai alat pengumpul data yang utama. Adanya hipotesis yang akan diuji kebenarannya melalui penelitian ini, maka jenis penelitian yang digunakan adalah explanatory research, yaitu penelitian yang menjelaskan hubungan kausal antara variabel-variabel melalui pengujian hipotesis. Variabel yang akan dijelaskan adalah persepsi dan program kewirausahaan di Perguruan Tinggi.

Jumlah populasi dalam penelitian ini adalah 400 orang mahasiswa yang memahami program kewirausahaan. Karena jumlah populasi relatif kecil maka jumlah sampel yang diambil sebagai responden sama dengan jumlah populasi. Sehingga metode pemilihan sampel menggunakan metode sensus. Dengan demikian jumlah sampel dalam penelitian ini adalah sebanyak 400 orang. Teknik pengambilan sampel yang digunakan yaitu sensus yakni jumlah populasi diambil seluruhnya sebagai sampel. Metode pengumpulan data sebagai berikut:

a. Kuesioner, berupa pertanyaan-pertanyaan yang disusun untuk diisi oleh responden. Maksudnya adalah untuk memperoleh data primer berupa informasi secara tertulis langsung dari responden mengenai variabel yang ditelti.

b. Dokumentasi, yaitu mengumpulkan informasi dengan mempelajari sumber data tertulis untuk memperoleh data sekunder mengenai latar belakang dan data tertulis lainnya yang mendukung penelitian ini.

Uji validitas digunakan untuk mengetahui sejauh mana data yang terkumpul tidak menyimpang dari gambaran variabel yang ditentukan atau dengan kata lain melalui uji validitas ini akan diketahui apakah item-item yang terdapat dalam kuesioner betul-betul dapat mengungkapkan apa yang akan diteliti. Cara yang digunakan yaitu menggunakan analisa butir atau istilah lainnya yaitu analisa item (Sugiyono, 2008), dimana setiap nilai yang ada pada setiap butir pertanyaan dikorelasikan dengan nilai total seluruh butir pertanyaan untuk suatu variabel dengan menggunakan rumus Korelasi Product Moment. Syarat minimum untuk dianggap valid adalah nilai $r$ $>0,30$.

Uji Reliabilitas dimaksudkan untuk mengetahui adanya konsistensi alat ukur dalam penggunaannya, atau dengan kata lain alat ukur tersebut dapat dikatakan reliabel jika secara konsisten menunjukkan hasil ukuran yang sama apabila digunakan berkalikali pada waktu yang berbeda. Jadi, reliabilitas merupakan suatu indeks yang menunjukkan sejauh mana instrumen dapat dipercaya atau dapat diandalkan. Untuk uji reliabilitas ini digunakan teknik 
Alpha Cronbach, dimana suatu instrumen dapat dikatakan handal (reliabel) bila memiliki koefisien keandalan atau alpha sebesar 0,6 atau lebih (Sugiyono, 2008).

Skala pengukuran yang digunakan dalam pengukuran variabel penelitian ini yaitu menggunakan skala likert yang menggunakan interval penilaian untuk setiap jawaban responden adalah 1 sampai 4. Interval jawaban responden akan disesuaikan dengan pertanyaan yang akan diajukan. Menurut Sugiyono (2008) skala likert ini berhubungan dengan pernyataan tentang sikap seseorang terhadap sesuatu, misalnya setuju-tidak setuju, senang-tidak senang, dan baik-tidak baik. Berikut ini akan diberikan contoh alternatif jawaban yang akan digunakan dalam kuesioner penelitian ini serta skor yang diberikan untuk setiap item pertanyaan:

- Sangat tidak puas

- Tidak puas

- Puas

- Sangat puas

diberi skor: 1

diberi skor: 2

diberi skor : 3

diberi skor: 4

Untuk menjawab permasalahan disesuaikan dengan model hipotesis, di mana untuk menguji hipotesis penelitian ini digunakan teknik analisis Regresi Linear Berganda dengan rumus sebagai berikut:

$Y=\beta_{0}+\beta_{1} X_{1}+\beta_{2} X_{2}+\beta_{3} X_{3}+\epsilon$

Keterangan:

$\mathrm{Y}=$ Program Kewirausahaan

$\beta_{0}=$ intersep

$\mathrm{X}_{1}=$ Pemberian Setereotip

$\mathrm{X}_{2}=$ Manajemen kesan

$\mathrm{X}_{3}=$ Emosi

$\epsilon=$ error terms

Dalam mengestimasi dengan menggunakan model regresi linear berganda, ada beberapa syarat yang harus diperhatikan yaitu:

1) Keseluruhan variabel yang masih berskala ordinal ditransfer terlebih dahulu pada skala interval dengan menggunakan Metode Successive Interval (MSI).

2) Pemenuhan asumsi-asumsi klasik. Beberapa asumsi klasik yang harus dipenuhi dalam model regresi menurut Santoso (2005) yaitu:

a. Uji multikolinearitas.

b. Uji Normalitas.

c. Uji Heterokedastisitas.

d. Uji Autokorelasi.
Dalam penelitian ini uji asumsi klasik meliputi uji multikolinearitas, normalitas, dan heterokedastisitas. Sedangkan uji autokorelasi tidak diujikan, karena uji autokorelasi digunakan untuk data time series.

\section{HASIL DAN PEMBAHASAN}

\section{Hasil Penelitian}

Hasil analisis tentang pengaruh variabel-variabel bebas yaitu variabel pemberian setereotip (X1), variabel manajemen kesan (X2), variabel Emosi (X3) terhadap program kewirausaan $(\mathrm{Y})$ dapat dilihat pada Tabel 1

Tabel 1 Hasil Analisis Berganda

\begin{tabular}{lcccc}
\hline \multicolumn{1}{c}{ Variabel } & $\begin{array}{c}\text { Koofisien } \\
\text { Regresi }\end{array}$ & $\mathbf{t}$ & Sig. t & $\boldsymbol{\beta}$ \\
\hline Pemberian setereotip (X1) & 0,205 & 2,336 & 0,010 & 0,242 \\
Manajemen kesan (X2) & 0,277 & 3,791 & 0,025 & 0,408 \\
Emosi (X3) & 0,283 & 3,745 & 0,001 & 0,384 \\
\hline Multiple R $=0,827$ & & & & \\
R.Square $=0,685$ & & & & \\
Adjusted R Square $=0,661$ & & & & \\
Fhitung =28,987 & & & & \\
Signifikan F =0,0000 & & & \\
Konstanta =5,336 & & &
\end{tabular}

Berdasarkan hasil analisis regresi berganda di atas, diperoleh persamaan regresi sebagai berikut:

$$
\mathrm{Y}=5,336+0,205 \mathrm{X} 1+0,277 \mathrm{X} 2+0,283 \mathrm{X} 3
$$

1. Pengaruh Variabel Bebas (X) terhadap Variabel Terikat (Y) secara Serempak

Pengaruh variabel bebas $(\mathrm{X})$ terhadap variabel terikat (Y) secara simultan menunjukkan hasil nilai $F_{\text {hitung }}$ adalah sebesar 28,987 dengan signifikan F sebesar 0,0000 atau lebih kecil 0,05 (5\%). Apabila dibandingkan dengan $\mathrm{F}$ tabel pada taraf nyata (alpha) 5\% memperlihatkan angka 1,66. Dengan demikian hasil $\mathrm{F}$ hitung $>\mathrm{F}$ tabel sehingga menolak Ho. Kondisi ini menuju suatu pernyataan bahwa secara simultan ketiga variabel bebas tersebut berpengaruh terhadap program kewirausahaan secara signifikan pada taraf nyata (alpha) 5\%. Sehingga hipotesis pertama dapat diterima. Artinya ketiga variabel bebas (X) yang meliputi variabel pemberian setereotip (X1), variabel manajemen kesan (X2), variabel Emosi (X3) terhadap program kewirausaan (Y) berpengaruh signifikan terhadap program kewirausahaan (Y).

Nilai multiple regresi sebesar 0,827 , kondisi ini menunjukkan bahwa ketiga variabel bebas 
mempunyai keeratan hubungan dengan variabel terikat sebesar 0,827 . Sedangkan dari hasil analisis memperlihatkan nilai koefisien determinasi atau $R$-Square sebesar 0,685 . Artinya bahwa variabel $\mathrm{Y}$ dipengaruhi oleh ketiga variabel bebas sebesar 68,50\% sedangkan sisanya $31,50 \%$ dipengaruhi oleh variabel lain. Dari nilai udjasted $R$-Square sebesar 0,661 menunjukkan bahwa secara pasti ada pengaruh yang kuat dari ketiga variabel bebas (X) terhadap variabel terikat $(\mathrm{Y})$ sebesar $66,10 \%$, sedangkan sisanya $33,90 \%$ dipengaruhi oleh variabel lain yang tidak diteliti dalam dalam penelitian ini.

2. Pengaruh Variabel Bebas (X) terhadap Variabel Terikat (Y) secara Parsial

Dari hasil analisis menunjukkan bahwa variabel orgnisasi mempunyai nilai positif $(+)$ dengan koefisien regresi sebesar 0,205. Tanda positif mempunyai arti bahwa variabel pemberian setereotip ternyata berpengaruh positif pada program kewirausahaan dengan kontribusi relatif sebesar 20,50\%, apabila variabel lain dianggap konstan. Berdasarkan hasil uji $\mathrm{t}$ diperoleh signifikan $\mathrm{t}<$ alpha $5 \%$ atau dapat dilihat dengan cara membandingkan $t$ hitung dengan $t$ tabel. Perhitungan menunjukkan nilai t hitung sebesar 2,336 sedangkan nilai $t$ tabel pada taraf nyata 5\% df. 40 adalah sebesar 2,021 sehingga $t$ hitung $>t$ tabel yang berarti variabel pemberian seterotip bepengaruh terhadap variabel program kewirausahaan dan mempunyai hubungan yang positif. Sedangkan apabila dilihat korelasi antara masingmasing variabel bebas dengan variabel terikat, maka besarnya nilai koefisien $\beta$ yaitu variabel pemberian setereotip adalah sebesar 0,205 yang berarti secara tidak langsung kontribusi yang diberikan oleh variabel pemberian setereotip terhadap program kewirausahaan adalah sebesar $20,50 \%$ dengan menganggap variabel lainnya konstan.

Hasil analisis variabel manajemen kesan menunjukkan nilai positif (+) dengan koefisien regresi sebesar 0,277 . Tanda positif mempunyai arti bahwa variabel manajemen kesan internal ternyata berpengaruh positif pada pemberian setereotip dengan kontribusi relatif sebesar $27,70 \%$, apabila variabel lain dianggap konstan. Hasil uji t variabel ini, diperoleh signifikan $\mathrm{t}<$ alpha $5 \%$ atau dapat dilihat dengan cara membandingkan $t$ hitung dengan $t$ tabel. Perhitungan menunjukkan nilai t hitung sebesar 3,791 sedangkan nilai $\mathrm{t}$ tabel pada taraf nyata $5 \%$ adalah sebesar 2,02, sehingga t hitung $>t$ tabel, sehingga variabel manajemen kesan bepengaruh terhadap variabel program kewiraushaan dan mempunyai hubungan yang positif. Sedangkan apabila dilihat korelasi antara masing-masing variabel bebas dengan variabel terikat, maka besarnya nilai koefisien $\beta$ yaitu variabel manajemen kesan adalah sebesar 0,408 yang berarti secara tidak langsung kontribusi yang diberikan oleh variabel manajemen kesan terhadap program kewiraushaan adalah sebesar 40,80\% dengan menganggap variabel lainnya konstan.

Hasil analisis menunjukkan bahwa variabel emosi mempunyai nilai positif $(+)$ dengan koefisien regresi sebesar 0,283 . Tanda positif mempunyai arti bahwa variabel emosi ternyata berpengaruh positif pada program kewirausahaan dengan kontribusi relatif sebesar $28,30 \%$, apabila variabel lain dianggap konstan. Hasil uji t variabel ini, diperoleh signifikan $\mathrm{t}<$ alpha 5\% atau dapat dilihat dengan cara membandingkan $\mathrm{t}$ hitung dengan $\mathrm{t}$ tabel. Perhitungan menunjukkan nilai $\mathrm{t}$ hitung sebesar 3,745 sedangkan nilai t tabel pada taraf nyata $5 \%$ adalah sebesar 2,02 , sehingga $\mathrm{t}$ hitung $>\mathrm{t}$ tabel, sehingga variabel emosi verpengaruh terhadap variabel program kewiraushaan dan mempunyai hubungan yang positif. Sedangkan apabila dilihat korelasi antara masingmasing variabel bebas dengan variabel terikat, maka besarnya nilai koefisien $\beta$ yaitu variabel emosi adalah sebesar 0,384 yang berarti secara tidak langsung kontribusi yang diberikan oleh variabel emosi terhadap program kewiraushaan adalah sebesar $38,40 \%$ dengan menganggap variabel lainnya konstan.

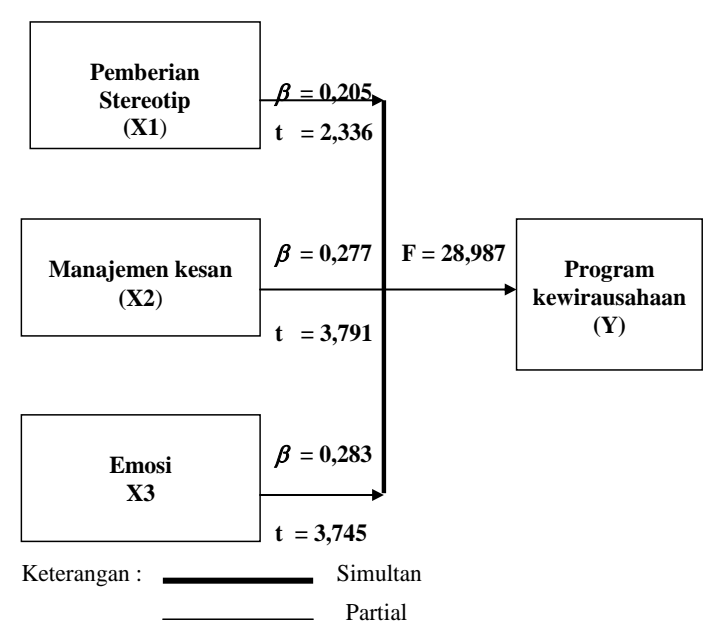

3. Pembuktian Hipotesis

Hipotesis I:

Diduga ada pengaruh yang signifikan variabel pemberian setereotip (X1), variabel manajemen kesan (X2), variabel emosi (X3) secara simultan terhadap variabel program kewirausahaan $(\mathrm{Y})$. 
Hasil analisis regresi diperoleh nilai $\mathrm{F}$ hitung sebesar 28,987 dengan signifikan $F$ sebesar 0,0000 $<5 \%$. Hal ini memperlihatkan bahwa Ho: $\beta_{1}=\beta_{2}$ $=\beta_{3} \neq 0$ Artinya secara simultan ketiga variabel bebas $(\mathrm{X})$ secara simultan terhadap variabel program kewirausahaan $(\mathrm{Y})$. Dengan demikian hipotesis I diterima.

\section{Hipotesis II:}

Diduga ada pengaruh yang signifikan variabel pemberian setereotip (X1), variabel manajemen kesan (X2), variabel emosi (X3) secara parsial terhadap variabel program kewirausahaan (Y).

Dari uji parsial diperoleh hasil nilai $t$ hitung variabel bebas $(\mathrm{X})$ yaitu variabel pemberian setereotip (X1) t hitung sebesar 2,336, variabel manajemen kesan (X2) $t$ hitung sebesar 3,791 dan variabel emosi (X3) $t$ hitung sebesar 3,745, berarti lebih besar dari nilai $t$ tabel 2,02. Hasil ini memperlihatkan bahwa Ho: bi $>0$ artinya ada pengaruh positif dan siginifikan dari variabel $\mathrm{Xi}$ terhadap variabel $\mathrm{Yi}$, atau ada pengaruh variabel pemberian setereotip (X1), variabel manajemen kesan (X2), variabel emosi (X3) secara parsial terhadap variabel program kewirausahaan $(\mathrm{Y})$. Dengan demikian hipotesis II diterima.

\section{Pembahasan Hasil Penelitian}

Pemberian stereotip merupakan tahap penerjemahan proses persepsi yang digunakan untuk membantu mahasiswa beradaptasi dengan berbagai program kewirausahaan yang dikembangkan dalam lingkungan kampus. Stereotip dalam keterbatasan kognitif individu cenderung jarang akurat menghasilkan suatu pemahaman yang dinginkan. Namun di kalangan mahasiswa stereotip untuk mengimplementasikan program kewirausahaan bisa dilaksanakan sebab mahasiswa memiliki tingkat adaptasi yang tinggi dan bisa menggunakan indra dan kemampuan atau sikap nalarnya dalam menterjemahkan program kewirausahaan di lingkungan kampus. Walaupun tidak di sangka efek halo dalam pengembangangan kewirausahaan bisa saja terjadi terutama bagi mahasiswa yang memang tidak tertarik dengan program ini. Namun dari sisi stereotip bisa dikatakan bahwa persepsi mahasiswa terhadap program kewirausahaan adalah positif.

Manajemen kesan dalam persepsi merupakan upaya seseorang memobilisasi sumber daya ketika ada stimulus dari luar. Program kewirausahaan merupakan suatu stimulus yang kemudian direspon oleh mahasiswa. Manajemen kesan dikalangan mahasiswa sangat penting, sebab untuk berinteraksi secara sosial yang memang menjadi persyaratan penting dalam tindakan kewirausahaan. Manajemen kesan memungkinkan mahasiswa untuk berupaya memberikan ketrampilan berkomunikasi, sebab keberhasilan dari suatu program kewirausahaan merupakan bagian dari suatu komunikasi bisnis. Menurut Jones dan Pitman dalam Ivancevich at al (2006) bahwa individu memperaktekan lima taktik manajemen kesan yaitu: (a) mengambil hati (integratiation), (2) mempromosikan diri (self-promotion), (3) memberikan contoh (exemplification), (4) memohon (supplication), (5) intimidasi (intimidation).

Penelitian menurut Ivancevich et al. (2006) telah menentukan delapan emosi primer utama: takut, terkejut, sedih, senang, jijik, marah, antisipasi, dan penerimaan. Kedelapan emosi utama bisa bervariasi dalam hal intensitas. Bentuk yang paling dari emosi disebut suasana hati (mood) . suasana hati merupakan keadaan emosional yang berintensitas rendah dan bertahan lama. Untuk menjalankan program kewirausahaan memang dibutuhkan suasana hati yang menyenangkan. Oleh sebab itu program kewirausahaan di lingkungan kampus harus berada pada situasi yang kondusif, agar memberikan respon emosi yang selalu segar dalam menjalankan aktivitas kewirausahaan.

\section{KESIMPULAN DAN SARAN}

Persepsi mahasiwa terhadap program kewirausahaan di perguruan tinggi adalah positif. Dari hasil analisis data persepsi mahasiswa memberikan kontribusi sebesar $66 \%$. Persepsi pemberian stereotip memberikan kontribusi sebesar 20,50\%, yang artinya apabila pemberian stereotip dinaikkan sebesar satu satuan maka program kewirausahaan akan meningkat sebesar 20,50\%. Persepsi manajemen kesan memberikan kontribusi sebesar $27,70 \%$, yang artinya apabila manajemen kesan dinaikkan sebesar satu satuan maka program kewirausahaan akan meningkat sebesar 27,70\%. Persepsi pada intesitas emosi memberikan kontribusi sebesar $28,30 \%$, yang artinya apabila emosi dinaikkan sebesar satu satuan maka program kewirausahaan akan meningkat sebesar $28.30 \%$.

Rekomendasi dari hasil penelitian adalah program pengembangan kewirausahaan di kampus, pelaksanaannya bisa ditindak lanjuti dalam bentuk pemberian modal kerja kepada mahasiswa secara berkelompok untuk membuka usaha sesuai dengan keinginannya, yang secara manajemen tetap dimonitor oleh pihak kampus. 


\section{DAFTAR PUSTAKA}

Pekerti, Anugerah. 1997. Mitos dan Teori dalam Pengembangan Kewirausahaan. Bahan Seminar Operasionalisasi KKNU dan KKB, UNISSULA. Semarang, 13 September.

Rye, David E. 1995. Tolls for Executives: The Vest Pocket Entrepreneur, Terjemahan, New Jersey: Prentice Hall.

Depnaker RI. 1999. "Situasi Tenaga Kerja dan Kesempatan Kerja di Indonesia (Suatu Tinjauan yang dilaksanakan pada tahun 1998)", Jakarta.

Geoffrey, G. \& Meredith. 1996. Kewirausahaan Teori dan Praktek, Jakarta: Pustaka Binaman Pressindo.

Instruksi Presiden RI No. 4. 1995. Gerakan Nasional emasyarakatkan dan Membudayakan Kewirausahaan, Jakarta.

Ivancevich, John M., Robert Konospaske \& Michael T. Matteson. 2006. Perilaku dan Manajmen Organisasi, Jakarta: Erlangga.

Lee, J. 2001. "Instructional Support for Distance Education and Faculty Motivation, Commit- ment, Satisfaction", British Journal of Educational Technology, page: 153-160.

Hoffman, Lorrie L., Cynthia J. Hutchinson. \& Elayne Reiss. 2009. "On Inproving School Climate: Reducing Reliance on Rewards and Punishment", International Journal of Whole Schooling, page: 1-16.

Luthans, Fred. 2006. Organizational Behaviour, Eleventh Edition, New York: McGraw-Hill.

Makalah Lokakarya Kewirausahaan Perguruan Tinggi, DP3M Dikti, Puncak Bogor, 18-20 Agustus 1997.

Robbins, Stephen. 2006. Perilaku Organisasi Jilid 2, Edisi Ketujuh, Versi Bahasa Indonesia. Jakarta: Prenhallindo.

Santoso, Singgih. 2005. SPSS Mengolah Data Statistik Secara Profesional, Cetakan Keempat, Jakarta: PT Elexmedia Komputindo.

Sugiyono. 2008. Metode Penelitian Bisnis, Bandung: CV Alfabeta.

Tim Broad-Based Education. 2002. "Pendidikan Berorientasi Kecakapan Hidup (Life Skill) Melalui Pendekatan Broad-Based Education (BBE)", Jakarta: Departemen Pendidikan Nasional. 